\title{
Taff Vale trunk road stage 4, South Wales 2: geotechnical design
}

\author{
L. Hinch and P. Fookes
}

\section{Mr C. D. Warren, Sir William Halcrow and Partners}

Having been actively involved throughout the duration of work in the role of Independent Design Checker, it is clear that the success of the installed geotechnical measures and flexibility of approach owed much to the adequacy of both instrumentation and on-site monitoring capabilities. This was particularly important with respect to the design and construction of drainage measures for the road as these were influenced not only by the anisotropy of the ground, partly the result of mining activities, but also by seasonal effects. A typical illustration of this is afforded by Fig. 21 which records the water level observations made in standpipe piezometers in response to pumping the surrounding wells located on the Taren Slip central zone. Observations of both drawdown and recovery suggested that recharge into this area was not infinite but was strongly influenced by both rainfall and the nature of the slip debris itself.

55. The major consequence of this finding is that in many engineering situations some caution is necessary when using summer pumping test data because this could lead to totally inadequate dewatering or drainage measures for a wet winter. For the Taff Vale trunk road such difficulties were recognized at an early stage with well spacing and arrangement being designed accordingly. Do the Authors consider that for many other construction projects such flexibility and on-site monitoring capabilities is generally lacking?

\section{Dr M. P. O'Reilly, Transport and Road Research Laboratory}

In $\S 45$ it states that in five of the six rock cuttings presplitting could not be attempted because the change necessary would have caused vibrations well in excess of the maximum permitted $50 \mathrm{~mm} / \mathrm{s}$ peak particle velocity. This may well be true where the charges are coupled in the presplitting holes but it has been shown ${ }^{8}$ that when decoupled charges are used for presplitting the vibration levels are much reduced and can be much the same or lower than those caused by bulk blasting for a given charge weight.

57. Presplit blasting has been developing apace on highway construction in Scotland during the past $10-15$ years. There is no doubt that the cuttings so produced are more stable and maintenance free than those produced by bulk blasting. An excellent description of the $62 \mathrm{~m}$ high Rubha Mor cutting on the banks of Loch Lomond has been published. ${ }^{9}$ Further details of presplit blasting techniques can be found in references 10 and 11 .

Paper published: Proc. Instn Civ. Engrs, Part 1, 1989, 86, Feb., 161-188. 


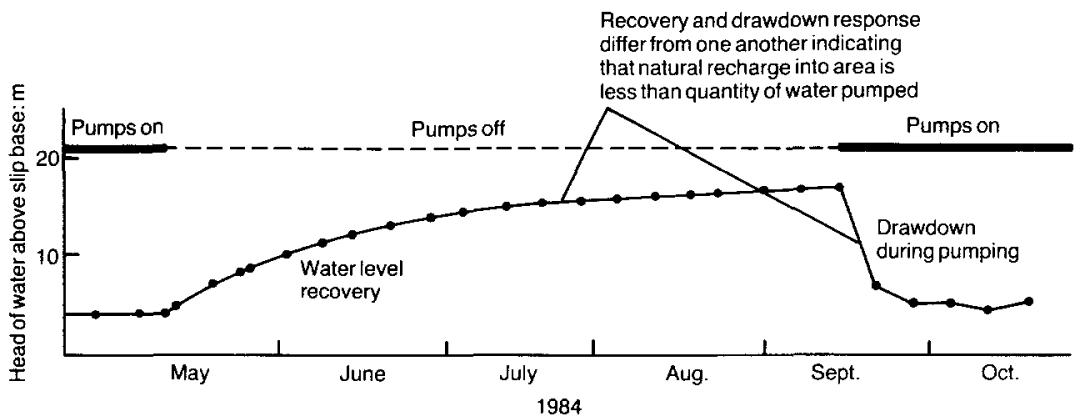

Fig. 21. Typical drawdown/recovery observations for standpipe piezometer sited in the central area

\section{Mr Hinch and Dr Fookes}

Mr Warren referred to the anisotropic nature of the ground and to the seasonal effects on recharge into the area. While the Authors have no specific knowledge of the normal practice of other engineers, flexibility in design and on-site monitoring is such an appropriate response to such conditions that we should be surprised if it were not commonly used.

59. Dr O'Reilly refers to the use of decoupled charges for presplitting as a means of reducing vibration levels. The contract specification required the contractor to propose the type, weight and distribution of explosives and the method of simultaneous detonation of groups of not less than 6 nor more than 12 holes. When it was found that the required vibration levels would be exceeded, neither the contractor nor his explosives manufacturer proposed the use of decoupled charges. Instead, the contractor elected to trim the face by impact hammers with a final trim by hand. The Engineer had no objection to this method as it had been used successfully on stages $1-3$ of the road.

60. It is noted from reference 10 that experience on successful presplit contracts in Scotland up to May 1982 appears to have been wholly in igneous and metamorphic rocks. On the Taff Vale stage 4 contract the rock cuttings were all in the sedimentary Pennant Measures and good results were obtained from controlled blasting which left reasonable faces bounded by the strong high angle north-south joint systems. Trimming by impact hammers and by hand was required where spalling occurred with the intersection of NE-SW and SE-NW joints, particularly when the dip of the bedding planes was unfavourable. The size of the wedges depended on the variations in the local joint and bedding plane spacing and attitude.

61. Fresh and slightly weathered rock occurred generally only near the base of the cuttings. Above this, the common occurrence of highly fractured sandstones, siltstones, seatearth and coals, frequently occupying a large proportion of the cut face (e.g. Figs 10, 11 and 20) required treatment as indicated in Fig. 9. Nevertheless it would have been valuable to observe the results of presplitting using decoupled charges on sandstone and to see the effect on the pattern and frequency of small wedge failures. 


\section{References}

8. NeW B. M. Ground vibration caused by civil engineering works. Transport and Road Research Laboratory research report 53, TRRL, Crowthorne, 1986, 10-11.

9. Howison J. A. and Macdonald A. Trunk road A82: the Loch Lomondside road: conception and implementation. Proc. Instn Civ. Engrs, Part I, 1988, 84, June, 497-517.

10. Matheson G. D. Presplit blasting for highway rock excavation. Transport and Road Research Laboratory report LR 1094, TRRL, Crowthorne, 1983.

11. Matheson G. D. The design and excavation of stable slopes in hard rock with particular reference to presplit blasting. Proc. Conf. on Rock Engineering and Excavation in an Urban Environment: Hong Kong 1986. Institution of Mining and Metallurgy, London. 